\title{
Effect of Organic and Conventional Systems Used to Grow Pecan Trees on Diversity of Soil Microbiota
}

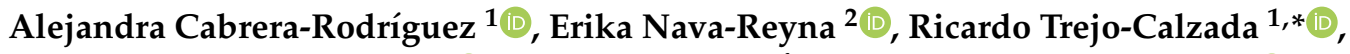 \\ Cristina García-De la Peña ${ }^{3}{ }^{\mathbb{D}}$, Jesús G. Arreola-Ávila ${ }^{1}$, Mónica M. Collavino ${ }^{4}{ }^{1}$, \\ Felipe Vaca-Paniagua ${ }^{5}$, , Clara Díaz-Velásquez ${ }^{5}$ and Vicenta Constante-García ${ }^{2}$
}

1 Unidad Regional Universitaria de Zonas Áridas, Universidad Autónoma Chapingo, carretera Gómez Palacio-Ciudad Juárez km 40, 35230 Bermejillo, Durango, Mexico; alejandra.cabrera@chapingo.uruza.edu.mx (A.C.-R.); jgarreola@chapingo.uruza.edu.mx (J.G.A.-Á.)

2 Centro Nacional de Investigación Disciplinaria en Relación Agua, Suelo, Planta, Atmósfera, Instituto Nacional de Investigaciones Forestales, Agrícolas y Pecuarias, Margen Derecho del Canal de Sacramento km 6.5, 35140 Gómez Palacio, Durango, Mexico; nava.erika@inifap.gob.mx (E.N.-R.); constante.vicenta@gmail.com (V.C.-G.)

3 Facultad de Ciencias Biológicas, Universidad Juárez del Estado de Durango, Av. Universidad s/n, Fracc. Filadelfia, 35010 Gómez Palacio, Durango, Mexico; cristina.garcia@ujed.mx

4 Instituto de Botánica del Nordeste, Facultad de Ciencias Agrarias, Universidad Nacional del Nordeste-CONICET, calle Sargento Cabral 2131, 34000 Corrientes, Argentina; mmcollavino@yahoo.com.ar

5 Laboratorio Nacional en Salud: Diagnóstico Molecular y Efecto Ambiental en Enfermedades Crónico-Degenerativas, Facultad de Estudios Superiores Iztacala, Universidad Nacional Autónoma de México, Av. de los Barrios 1, Los Reyes Iztacala, 54090 Tlalnepantla, Estado de México, Mexico; felipe.vaca@gmail.com (F.V.-P.); cdiazvelasquez@aol.com (C.D.-V.)

* Correspondence: rtrejo@chapingo.uruza.edu.mx

Received: 16 October 2020; Accepted: 16 November 2020; Published: 19 November 2020

\begin{abstract}
Agronomic management modifies the soil bacterial communities and may alter the carbon fractions. Here, we identify differences in several chemical and biological soil variables, as well as bacterial composition between organic (Org) and conventional (Conv) agronomic management in pecan (Carya illinoinensis) orchards located in Coahuila, Mexico. The analyzed variables were $\mathrm{pH}$, $\mathrm{N}, \mathrm{P}, \mathrm{K}$, soil organic matter, organic matter quality, soil organic carbon, $\mathrm{C} / \mathrm{N}$ ratio, carbon fractions, microbial biomass carbon, easily extractable Glomalin, colony-forming units, $\mathrm{CO}_{2}$ emissions, and the enzyme activity. The DNA of soil bacteria was extracted, amplified (V3-V4 16S rRNA), and sequenced using Illumina. To compare variables between agronomic managements, $t$ tests were used. Sequences were analyzed in QIIME (Quantitative Insights Into Microbial Ecology). A canonical correspondence analysis (CCA) was used to observe associations between the ten most abundant phyla and soil variables in both types of agronomic managements. In Org management, variables related to the capture of recalcitrant carbon compounds were significant, and there was a greater diversity of bacterial communities capable of promoting organic carbon sequestration. In Conv management, variables related to the increase in carbon mineralization, as well as the enzymatic activity related to the metabolism of labile compounds, were significant. The CCA suggested a separation between phyla associated with some variables. Agronomic management impacted soil chemical and biological parameters related to carbon dynamics, including bacterial communities associated with carbon sequestration. Further research is still necessary to understand the plasticity of some bacterial communities, as well as the soil-plant dynamics.
\end{abstract}

Keywords: organic agriculture; soil organic carbon; $16 \mathrm{~S}$ rRNA; sequencing; structure of the soil bacterial community 


\section{Introduction}

Microorganisms that live in the soil are among the most abundant and diverse organisms on earth [1]. The structure and metabolism of the soil bacterial communities are influenced by elements of the ecosystem such as climate, type of soil, and plant composition; however, one factor that greatly affects their composition and functioning is agronomic management [2-5]. Thus, conventional agronomic management (CAM) alters the distribution of organic material and affects the rate of mineralization of micro and macro elements in the soil [3], negatively impacting the long-range productivity of the soil due to the loss of organic matter and erosion [6]. In CAM, inorganic supplies, such as synthetic fertilizers and pesticides, are used [7]. These supplies affect the availability of nutrients in the soil, contaminating the surface and underground water, thus affecting the native biotic community [8]. Conversely, in organic management, the traditional cultivation methods (conservationist) are combined with modern techniques, excluding conventional supplies [9]. In these systems, crop rotation is practiced and residues from animals and organic vegetables are used to increase soil fertility and productivity [7-10]. Likewise, it has been reported that these practices also affect the long-term structure of the microbial community through the accumulation and chemistry changes of soil organic matter (SOM) [2].

Regarding the above, greater attention should be given to organic agricultural systems in perennial woody crops with commercial interest, such as pecan trees (Carya illinoinensis). These systems have the potential to improve soil fertility through microbial activity and carbon accumulation in the soil [10-13]. For pecan tree orchards, the essential practices to promote soil fertility involve using leguminous plants or wild herbs as ground cover, as well as using organic fertilizers [14]. The pecan tree is a perennial woody crop which produces the pecan nut, which is a highly nutritious food [15]. The world's leading producers of pecan nuts are China, United States, Iran, Turkey, and Mexico [16]. Furthermore, in Mexico, the states with a greater volume of pecan production are Chihuahua, Sonora, and Coahuila. These pecan nuts are exported mainly to the United States, China, and Vietnam, at an annual amount in 2018 worth USD 751 million [17]. Considering the cultivation of organic pecan trees in Mexico, in 2011 there were 1000 hectares certified as organic [14].

Given the importance of preserving and increasing soil fertility in pecan tree cultivation, several research studies have been developed to determine soil organic carbon (SOC), SOM, carbon-nitrogen relation, the mineralization of carbon and nitrogen, microbial biomass carbon, enzyme activities in diverse management systems, age of the crops, and association with leguminous plants and grasses $[11,12,18]$. Other research has focused on the qualities of the essential oils in nuts and on the nutritional deficiencies of the foliage, as well as on pests and diseases $[15,19,20]$. However, although the role of microbial communities in carbon sequestration is relevant, there are not enough research studies related to the structure and functioning of bacterial communities in the soil wherein pecan trees are grown under different agronomic management. Therefore, the objectives of this study were to identify the soil variables that respond to agronomic management related to carbon dynamics, and to determine the structure and composition of the bacterial communities in the soil wherein pecan trees are grown under organic and conventional management. We hypothesize that the organic management of pecan tree cultivation will generate greater soil bacterial diversity, capable of promoting greater efficiency in carbon sequestration than conventional management.

\section{Materials and Methods}

\subsection{Study Area}

Soil samples were collected from pecan orchards (Carya illinoinensis (Wangenh.) K. Koch) containing Cheyenne, Wichita, and Western varieties under organic (Org) and conventional (Conv) managements, located in the municipality of Allende, Coahuila, Mexico (Org: N 28 20'05.72" W -100 49'24.73"; Conv: N 28 $21^{\prime} 57.30^{\prime \prime}$ and $\mathrm{W}-100^{\circ} 46^{\prime} 06.02^{\prime \prime}$ ) (Figure 1). Both orchards are located in the same geographical region, where the type of soil corresponds to haplic xerosol and the texture is clay [21]. 
The prevalent climate is dry and semi-warm, where annual mean temperature ranges between 20 and $24{ }^{\circ} \mathrm{C}$, and the annual mean rainfall is about $461 \mathrm{~mm}$ [22]. The orchard under organic management (100 ha) is 20 years old, and the commonly applied practices to the soil are the use of plant covers and the placing of organic matter (pecan tree residues). On the other hand, the orchard under conventional management ( $35 \mathrm{ha}$ ) is 30 years old, and chemical fertilizers and pesticides are applied in accordance with the technical guide for pecan tree management proposed by INIFAP (Instituto Nacional de Investigaciones Forestales Agrícolas y Pecuarias) [23].

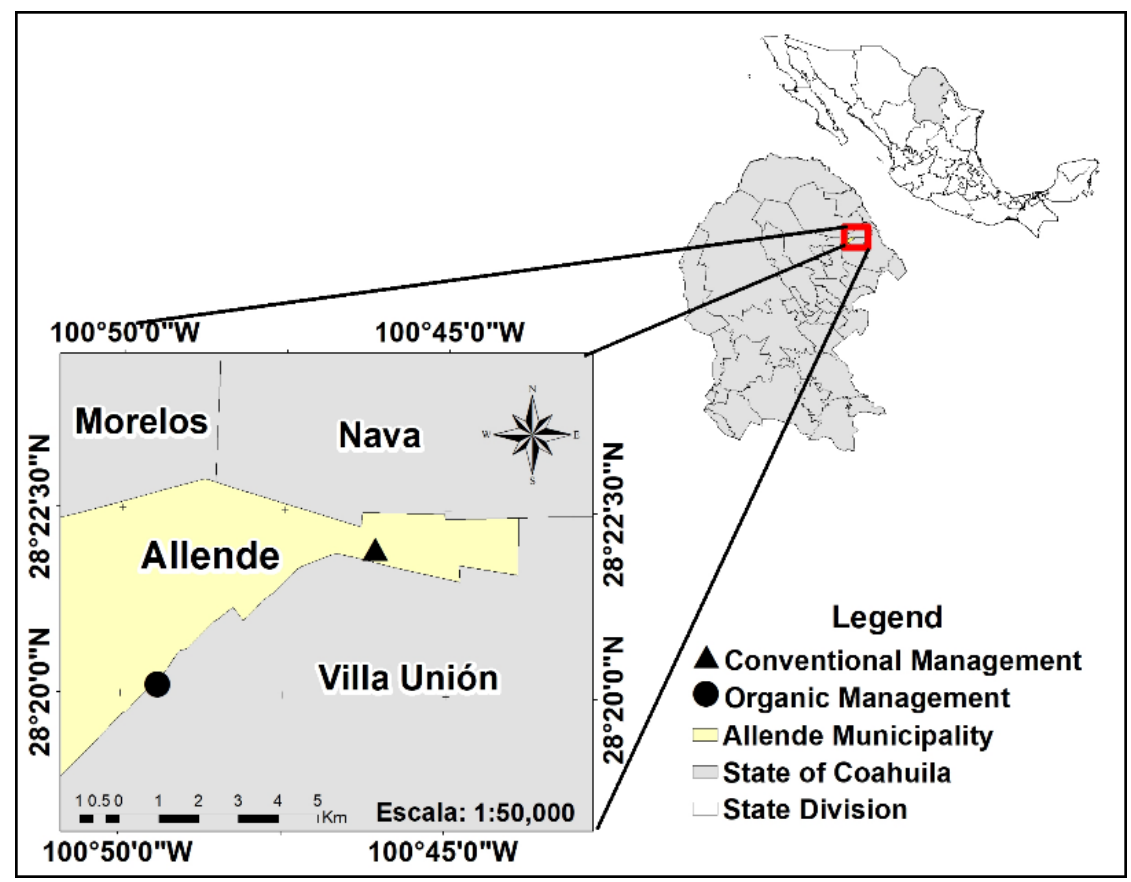

Figure 1. Geographical location of pecan tree (Carya illinoinensis) orchards in Coahuila, Mexico.

\subsection{Soil Sampling and Analysis of Chemical and Biological Variables}

Four pecan trees were systematically selected from each orchard. From each tree, four sub-samples were taken (one from each cardinal point) at a depth of $20 \mathrm{~cm}$. Respective sub-samples were mixed obtaining composite samples (approximately $1 \mathrm{~kg}$ each). The samples were air-dried and sieved using a $2 \mathrm{~mm}$ mesh before analytical determinations. The $\mathrm{pH}$ was determined with a soil/water ratio of 1:2 [24]. The essential nutrients, nitrogen $(\mathrm{N})$ [25], phosphorous (P) [26] and potassium (K) [27], were quantified. Likewise, the SOM [28] and the organic matter quality (humic acids (HA), fulvic acids (FA), and humins (HS) $[29,30]$ ) were obtained. The SOC was obtained using a total organic carbon analyzer (TOC), and later the $\mathrm{C} / \mathrm{N}$ ratio was estimated. Furthermore, the carbon fractions very labile (F1), labile (F2), less labile (F3) and recalcitrant (F4) were analyzed by digestion with $\mathrm{H}_{2} \mathrm{SO}_{4}$ at concentrations of 12, 18, and $24 \mathrm{~N}$ [31]. The microbial biomass carbon (MBC) was analyzed using the extraction fumigation method [32]. Furthermore, the easily extractable Glomalin (EEG) was determined [33], as well as the colony-forming units (CFU) by plate count (trypticase soy agar (total aerobic bacteria) and potato dextrose agar (PDA) (filamentous fungi and yeasts). Additionally, the $\mathrm{CO}_{2}$ emissions from the soil were measured over 42 days under controlled conditions of humidity and temperature [34,35]. Furthermore, the enzyme activity of the soil was evaluated for lacasse (LAC), peroxidase (PER), polyphenol oxidase (PPO) [36,37], B-glucosidase (B-glu), and B-galactosidase (B-gal) [38].

\subsection{DNA Extraction, Amplification and Sequencing}

Three trees from each pecan orchard were randomly selected to collect $0.25 \mathrm{~g}$ of soil from the rhizosphere zone, at a depth of $10 \mathrm{~cm}$. Each sample was placed in a BashingBead ${ }^{\mathrm{TM}}($ Zymo Research 
Corp., Irvine, CA, USA) cell lysis tube, containing $750 \mu \mathrm{L}$ of lysing/stabilizing solution. Each tube was processed in a cellular disruptor (TerraLyzer ${ }^{\mathrm{TM}}$ ) for $30 \mathrm{~s}$; samples were kept at ambient temperature. DNA was extracted using a Zymo BIOMICS ${ }^{\mathrm{TM}}$ (Zymo Research Corp., Irvine, CA, USA) kit. The amount of DNA obtained was measured in a Qubit fluorometer (Invitrogen, Carlsbad, CA, USA). The V3-V4 region of the 16S rRNA gene was amplified using primers suggested by Klindworth et al. [39] (S-D-Bact-0341-b-S-17, 5'-CCTACGGGNGGCWGCAG-3' and S-D-Bact-0785-a-A-21, $5^{\prime}$-GACTACHVGGGTATCTAATCC-3', ( 460 pb amplicon)) using the Illumina protocol [40]. The amplicons were purified with Agentcourt ${ }^{\circledR}$ AMPure ${ }^{\circledR}$ XP $0.8 \%$ beads (Beckman Coulter Inc., Brea, CA, USA). The Nextera XT Index $\mathrm{Kit}^{\mathrm{TM}}$ was used to create the library, following the Illumina protocol [41]. The library quantification, normalization (equimolarity) and next-generation massive sequencing ((MiSeq; Illumina, San Diego, CA, USA) $2 \times 250$ paired final readings) were developed following the $16 \mathrm{~S}$ metagenomic protocol [40]. Sequence data were submitted to The National Center for Biotechnology Information (GenBank), with the following accession numbers: Org samples (SAMN15365245, SAMN15365246, SAMN15365247), Conv samples (SAMN15365249, SAMN15365250, SAMN15365252).

\subsection{Statistical Analysis}

After verifying normality and homogeneity of variance, Student's $t$ test or Welch's $t$ test $(p<0.05)$ were used to compare the chemical and biological variables between pecan orchards. The DNA sequences were analyzed using Quantitative Insights Into Microbial Ecology (QIIME) [42] as suggested by García-De la Peña et al. [43]. The absolute abundance of OTUs at genus level was used to visualize the number of sequences vs. the number of OTUs to observe depth cover (asymptote curves); this graph was made in PAST ver 3.15 (44). A simple random rarefaction process was made to standardize all samples. Using the standardized file, relative abundances for the phylum level were obtained and represented as bar charts using Excel. Taxa at the genera level with a relative abundance greater than $1 \%$ were listed. Finally, a canonical correspondence analysis (CCA) was used to observe associations between the ten most abundant phyla and soil variables in both types of agronomic managements. The CCA was made in PAST [44].

\section{Results}

\subsection{Chemical and Biological Variables of the Soil}

Some chemical and biological variables of the soil showed significant differences between both orchards. The significantly higher variables in soil under Org management were N, P, SOC, MBC, and HS. For Conv management, the soil variables that showed significantly higher values were $\mathrm{F} 2, \mathrm{CO}_{2}$ emission, EEG, HA, FA, LAC, B-glu, and B-gal (Table 1).

\subsection{Abundance of Bacterial Taxa}

The average number of sequences assembled for Org was 230,680, and for Conv it was 267,539. After taxonomic designation, averages of 28,062 bacterial sequences for Org, and 48,775 for Conv, were obtained. The average number of OTUs was 5995 for Org, and 7937 for Conv (Table 2). Simple random rarefaction was made at 20,000 sequences, since at this point the number of OTUs reached asymptotes (Figure 2). 
Table 1. Chemical and biological characteristics of soil in pecan tree (Carya illinoinensis) orchards under organic and conventional management in Coahuila, Mexico. Mean values and standard deviation $( \pm)$ are shown. An asterisk indicates when a Welch's $t$ test was used; $\mathrm{df}=$ degrees of freedom; bold numbers indicate significant differences between managements $(p<0.05)$.

\begin{tabular}{|c|c|c|c|c|c|}
\hline Variable & Organic & Conventional & $t$ & df & $p$ \\
\hline $\mathrm{pH}$ & $8.1 \pm 0.09$ & $8.1 \pm 0.05$ & 1 & 3 & 0.391 \\
\hline Nitrogen \% & $0.050 \pm 0.004$ & $0.043 \pm 0.003$ & 3.13 & 6 & 0.020 \\
\hline Phosphorous mg kg ${ }^{-1}$ & $16.3 \pm 5.80$ & $5.6 \pm 1.00$ & 4.901 & 6 & 0.003 \\
\hline Potassium mg L $\mathrm{L}^{-1}$ & $0.52 \pm 0.31$ & $0.31 \pm 0.19$ & 2.06 & 3.14 & $0.127 *$ \\
\hline Organic Matter\% & $2.97 \pm 0.31$ & $3.11 \pm 0.11$ & -812 & 6 & 0.448 \\
\hline Organic Carbon \% & $1.91 \pm 0.04$ & $1.72 \pm 0.02$ & 7.071 & 6 & 0.000 \\
\hline Relation C/N\% & $38.6 \pm 3.10$ & $40.5 \pm 2.00$ & -1.116 & 6 & 0.307 \\
\hline Very labile fraction $\mathrm{C} \mathrm{g} \mathrm{kg}^{-1}$ & $12.30 \pm 1.35$ & $12.80 \pm 1.59$ & -0.522 & 6 & 0.620 \\
\hline Labile fraction $\mathrm{C} \mathrm{g} \mathrm{kg}^{-1}$ & $7.57 \pm 0.70$ & $10.65 \pm 0.45$ & -6.392 & 6 & 0.001 \\
\hline Less labile fraction ${\mathrm{C} \mathrm{kg}^{-1}}^{-1}$ & $18.67 \pm 3.17$ & $18.50 \pm 0.91$ & -0.068 & 6 & 0.948 \\
\hline Recalcitrant fraction $\mathrm{C} \mathrm{g} \mathrm{kg}^{-1}$ & $4.94 \pm 3.03$ & $2.43 \pm 0.49$ & 1.822 & 3.58 & $0.151 *$ \\
\hline Mineralization of $\mathrm{C} \mathrm{mg} \mathrm{CO}_{2} \mathrm{~g}^{-1}$ & $176.0 \pm 29.30$ & $278.5 \pm 64.80$ & -2.781 & 6 & 0.032 \\
\hline Easily Extractable Glomalin $\mathrm{mg} \mathrm{g}^{-1}$ & $0.5 \pm 0.00$ & $0.8 \pm 0.00$ & -9.076 & 6 & 0.000 \\
\hline Microbial biomass carbon $\mu \mathrm{g} C \mathrm{~g}^{-1}$ & $751.1 \pm 73.70$ & $77.0 \pm 0.00$ & 45.195 & 3 & 0.000 \\
\hline Colony forming units $\mathrm{g}^{-1}$ & $516,000 \pm 323,777$ & $1,200,777 \pm 701,683$ & -1.516 & 6 & 0.180 \\
\hline Humic acids $\mathrm{mg} \mathrm{C} \mathrm{kg}^{-1}$ & $1657.4 \pm 91.90$ & $2618 \pm 181.80$ & -10.464 & 6 & 0.000 \\
\hline Fulvic acids $\mathrm{mg} \mathrm{C} \mathrm{kg}^{-1}$ & $8671.4 \pm 144.20$ & $9632.2 \pm 144.10$ & -8.497 & 6 & 0.000 \\
\hline Humins $\mathrm{mg} \mathrm{C} \mathrm{kg}^{-1}$ & $14,316.3 \pm 221.80$ & $7350 \pm 166.40$ & 50.229 & 6 & 0.000 \\
\hline Peroxidase $\mu \mathrm{mol} \mathrm{g}^{-1} \mathrm{~h}^{-1}$ & $4.34 \pm 0.71$ & $4.50 \pm 0.16$ & -0.472 & 6 & 0.653 \\
\hline Polyphenol oxidase $\mu \mathrm{mol} \mathrm{g}-1 \mathrm{~h}^{-1}$ & $6.41 \pm 0.53$ & $7.23 \pm 0.57$ & -2.021 & 6 & 0.090 \\
\hline Lacasse $\mu \mathrm{mol} \mathrm{g}^{-1} \mathrm{~h}^{-1}$ & $0.02 \pm 0.01$ & $0.18 \pm 0.00$ & -13 & 6 & 0.000 \\
\hline B-glucosidase mg PNP g ${ }^{-1}$ & $145.1 \pm 7.20$ & $510.6 \pm 19.5$ & -42.287 & 6 & 0.000 \\
\hline B-galactosidase $\mathrm{mg} \mathrm{PNP} \mathrm{g}^{-1}$ & $24.2 \pm 9.50$ & $54.4 \pm 1.00$ & -4.608 & 3.03 & 0.019 * \\
\hline
\end{tabular}

Table 2. Soil bacterial sequences of pecan tree (Carya illinoinensis) orchards under organic (Org) and conventional (Conv) management in Coahuila, Mexico. $\mathrm{CD}=$ chimeras discarded, $\mathrm{QS}=$ quality sequences after chimeras were discarded, BS = bacterial sequences, OTUs = operational taxonomic units.

\begin{tabular}{cccccccc}
\hline Sample & Total & Assembled & Discarded & CD & QS & BS & OTUs \\
\hline Org 1 & 278,980 & 68,366 & 210,608 & 568 & 67,798 & 27,154 & 6014 \\
Org 2 & 225,583 & 52,984 & 172,599 & 486 & 52,498 & 22,087 & 5594 \\
Org 3 & 187,477 & 57,859 & 129,607 & 610 & 57,249 & 34,945 & 6377 \\
Mean & 230,680 & 59,736 & 170,938 & 555 & 59,182 & 28,062 & 5995 \\
Conv 1 & 212,217 & 51,586 & 160,618 & 523 & 51,063 & 33,292 & 6022 \\
Conv 2 & 272,201 & 83,983 & 188,207 & 870 & 83,113 & 53,264 & 8653 \\
Conv 3 & 318,199 & 94,434 & 223,744 & 842 & 93,592 & 59,769 & 9135 \\
Mean & 267,539 & 76,668 & 190,856 & 745 & 75,923 & 48,775 & 7937 \\
\hline
\end{tabular}

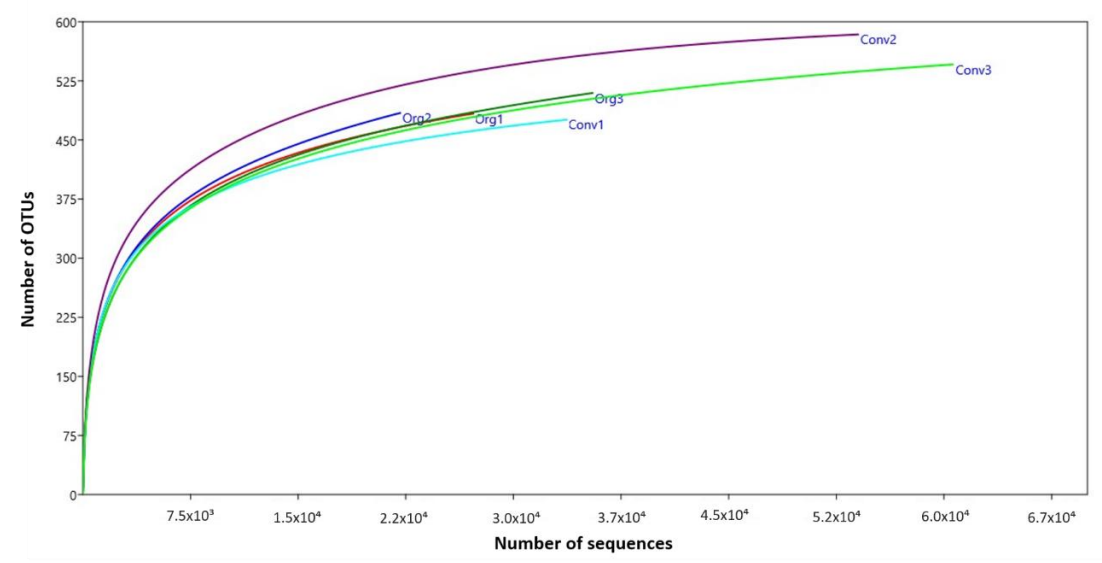

Figure 2. Rarefaction curves for soil bacteria OTUs identified from pecan tree (Carya illinoinensis) orchards under organic (Org) and conventional (Conv) management in Coahuila, Mexico. 
For Org management, the most abundant phyla were Proteobacteria $(\overline{\mathrm{x}}=36 \%)$, Actinobacteria $(\bar{x}=24 \%)$, Planctomycetes $(\bar{x}=18 \%)$ and Chloroflexi $(\bar{x}=13 \%)$, (Figure 3a). A similar phyla composition was observed for the Conv management: Proteobacteria $(\bar{x}=32 \%)$, Actinobacteria $(\bar{x}=26 \%)$, Planctomycetes $(\bar{x}=19 \%)$ and Chloroflexi $(\bar{x}=15 \%)$, (Figure 3b). The remaining phyla were Acidobacteria, Gemmatimonadetes, Verrumicrobia, Cyanobacteria, Parcubacteria, and Saccharibacteria.

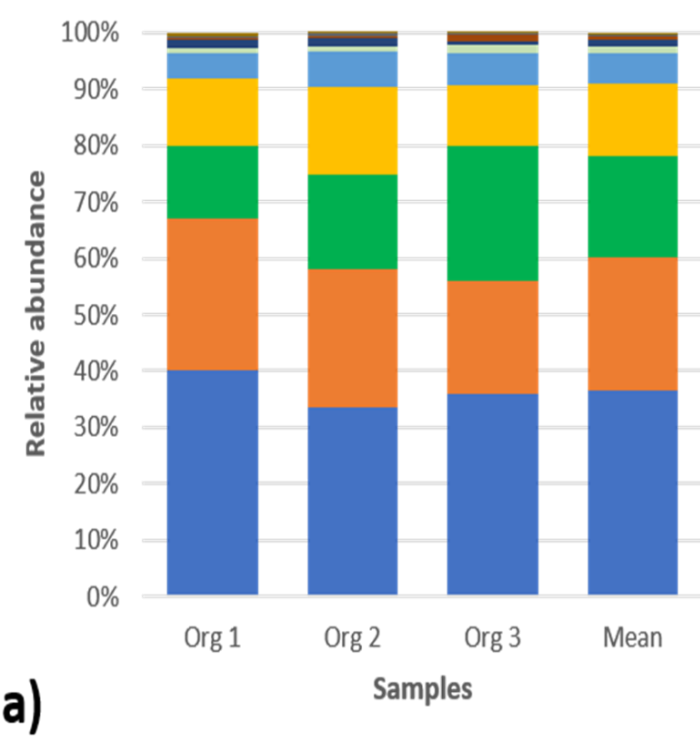

- Armatimonadetes

- Cyanobacteria

- Verrucomicrobia

- Gemmatimonadetes

- Saccharibacteria

- Acidobacteria

- Chloroflexi

- Planctomycetes

- Actinobacteria

- Proteobacteria

a)

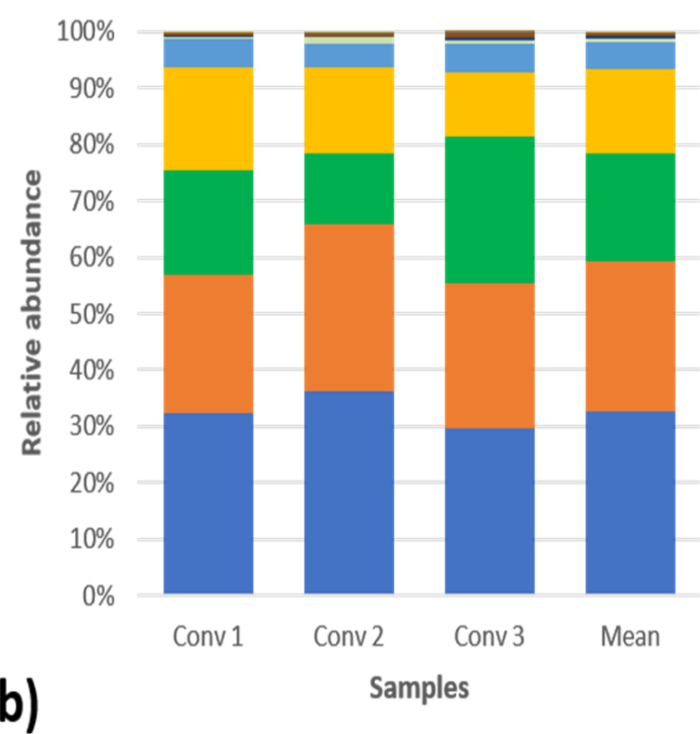

- Armatimonadetes

- Cyanobacteria

- Verrucomicrobia

- Gemmatimonadetes

- Saccharibacteria

- Acidobacteria

Chloroflexi

- Planctomycetes

Actinobacteria

- Proteobacteria

\section{b)}

Figure 3. Relative abundance (\%) per sample and means of the main bacterial phyla in soil samples of pecan tree (Carya illinoinensis) orchards under organic (a) and conventional (b) management in Coahuila, Mexico.

A total of 776 bacterial genera was obtained, of which 29 had a relative abundance greater than $1 \%$ (20 had a taxonomical name, and 9 had a taxonomical key). The three more abundant cultivated genera were Tepidisphaera $(\overline{\mathrm{x}}=7.1 \%)$, Sphingomonas $(\overline{\mathrm{x}}=3.2 \%)$, and Gemmata $(\overline{\mathrm{x}}=4.0 \%)$. The first two genera were more representative in the Conv management, while the third one was more representative in the Org management. The remaining genera were Dongia, Microvirga, Sphingosinicella, Streptomyces, Rhizomicrobium, Stenotrophobacter, Pseudolabrys, Zavarzinella and Catelliglobosispora; all of these were present in both managements (Table 3). 
Table 3. Relative abundance of the bacterial genera found in the soil of pecan tree (Carya illinoinensis) orchards under organic and conventional management in Coahuila, Mexico. Only those genera whose relative abundance was $\geq 1 \%$ are shown. Asterisks indicate greater abundance according to the type of management.

\begin{tabular}{ccc}
\hline Genera & \multicolumn{2}{c}{ Relative } \\
Organic & $\begin{array}{c}\text { Abundance } \% \\
\text { Conventional }\end{array}$ \\
\hline Tepidisphaera & 3.8 & $7.1^{*}$ \\
GQ396871 & 3.9 & 3.7 \\
Sphingomonas & 2.6 & $3.2^{*}$ \\
Gemmata & $4.0^{*}$ & 3.1 \\
Dongia & $3.1^{*}$ & 2.1 \\
FJ478799 & 4.2 & 2.0 \\
Microvirga & 0.9 & $1.9^{*}$ \\
GQ263023 & 1.4 & 1.8 \\
Sphingosinicella & 0.5 & $1.7^{*}$ \\
Streptomyces & 1.5 & $1.6^{*}$ \\
Rhizomicrobium & 1.1 & $1.3^{*}$ \\
EU335288 & 0.9 & 1.2 \\
AF370880 & 1.6 & 1.2 \\
FJ479444 & 0.7 & 1.2 \\
Stenotrophobacter & 0.9 & $1.2^{*}$ \\
EF125410 & 0.3 & 1.2 \\
EU669599 & 0.3 & 1.1 \\
Pseudolabrys & $1.2^{*}$ & 1.1 \\
Zavarzinella & $1.7^{*}$ & 1.1 \\
EU335161 & 1.1 & 1.0 \\
Catelliglobosispora & $1.2^{*}$ & 1.0 \\
\hline
\end{tabular}

The CCA suggested that in both managements there is a separation between the phyla, which is associated with some chemical and biological characteristics of the soil. However, this separation was visible only in the second axis (Figure 4). Regarding axis 1, the phyla located left of the " $y$ " axis belong to Gemmatimonadetes, Cyanobacteria, Parcubacteria, Chloroflexi, Actinobacteria, Proteobacteria, and Saccharibacteria-the same that are favored by PER (-0.64) and F3 (-0.62). In contrast, on the right side of the " $y$ " axis, the Verrumicrobia, Planctomycetes and Acidobacteria phyla were located in association with $\mathrm{pH}(0.66)$ and $\mathrm{C} / \mathrm{N}(0.94)$. Above the " $\mathrm{x}$ " axis, the Org management samples were found, wherein the phyla belonging to Gemmatimonadetes, Parcubacteria, Proteobacteria, Cyanobacteria, Acidobacteria, and Verrumicrobia were favored by the presence of HS (0.96). On the other hand, the phyla located below the " $\mathrm{x}$ " axis were Chloroflexi, Actinobacteria, Planctomycetes and Saccharibacteria, which were associated with EEG (-0.98), FA (-0.97) and B-glu (-0.97).

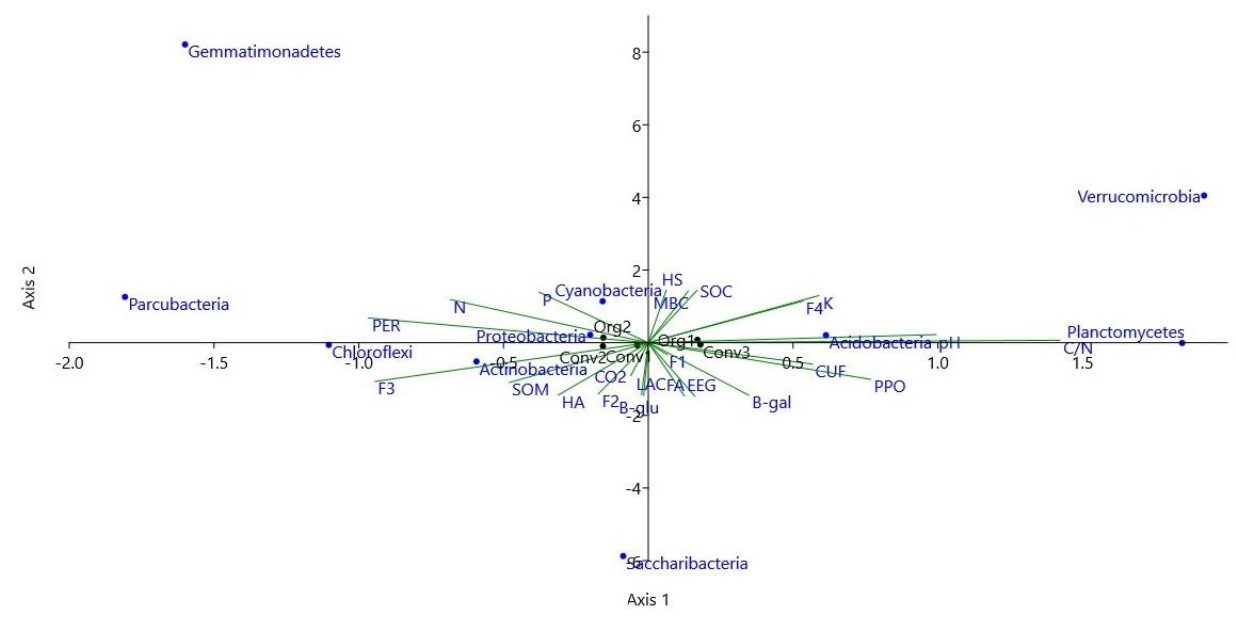

Figure 4. Canonical correspondence analysis of soil from pecan tree (Carya illinoinensis) orchards under organic and conventional management in Coahuila, Mexico, identifying associations among the main phyla and the evaluated soil variables. 


\section{Discussion}

\subsection{Chemical and Biological Variables of the Soil}

The management of the soil in agricultural systems affects its physical, chemical and biological characteristics [5]. It has been demonstrated that the concentration of $\mathrm{N}$ is higher in soils under Org management, due to the abundance of microorganisms capable of mineralizing $\mathrm{N}$ more efficiently $[2,45]$. Likewise, the addition of organic amendments generates a greater availability of nutrients such as $\mathrm{P}$, which is mainly found in humic substances or in the microbial biomass of the soil [46,47]. In this study, the SOC content was higher than reported by other authors in pecan tree orchards [11,18]. In addition, HS are considered to be the most recalcitrant fraction of the organic soil and, therefore, are able to stay in the soil for longer [48]. It is likely that most of the SOC under Org management will be stabilized in less labile and recalcitrant forms. With respect to MBC, it has been shown that its content increases with the long-term establishment of plant cover, as in this study [49,50], while nitrogen fertilization tends to decrease it [51]. Likewise, it is the main agent of SOM decomposition, transforming nutrients and making them available [52], which may explain the high content of MBC and the low percentages of SOM in pecan orchards under Org management. In contrast, it has been shown that the F2 fraction has a high rate of decomposition and a shorter residence time in the soil [53], thus responding to Conv management by releasing carbon into the atmosphere in the form of $\mathrm{CO}_{2}$, causing losses of nutrients and soil fertility [54] - contrary to what happens in soil Org management [55,56]. On the other hand, organic materials with a low degree of humification, i.e., labile, increase the HA and FA fractions [57,58]. According to Vásquez et al. [59], there is a positive correlation between $\mathrm{CO}_{2}$ emissions and carbon labile fractions. Carbon loss in the form of $\mathrm{CO}_{2}$ is caused by the decomposition of SOM by heterotrophic microorganisms, and occurs mainly when there is an increase in the availability of SOM and when it lacks a biochemical composition enriched with recalcitrant organic compounds, which makes it more difficult for microorganisms to disintegrate [60]. The results herein reported suggest that in the pecan tree orchard under Conv management, in spite of the fact that the content of SOM is greater than under Org management, the SOC is less stable and could easily be lost in the form of $\mathrm{CO}_{2}$, because the SOM lacks recalcitrant organic compounds [60-62].

Agronomic management is influential in the increase of concentrations of glomalin [63], which agrees with the current study since the amount of glomalin was greater in Conv management. In this regard, the high concentration of $\mathrm{CO}_{2}$ produces effects in the increase of the glomalin reserves [64], which suggests that glomalin is related to the high respiration rate in soils under Conv management. Furthermore, the oxidative enzyme LAC (EC 1.10.3.2) participates in the degradation and biosynthesis of lignin, and its activity may be increased by substrates that degenerate rapidly, such as cellobiose and glucose, and with an increase in fungi growth $[65,66]$. The above may suggest that the increase in oxidative enzymatic activity in the soil under Conv management may be due to the presence of substrates that may easily be degraded by fungi, which could also explain the high content of glomalin under this same management. As for $\beta$-glu (EC 3.2.1.21), it participates in the hydrolysis of cellobiose to glucose [67], degrading plant cell walls and contributing to the first phases of plant cell tissue decomposition [68]. The increased activity of $\beta$-gal (EC 3.2.1.23) may suggest that soil microorganisms are metabolically more active with rapid proliferation, thus increasing the efficiency of enzyme production [69]. Furthermore, as these enzymes degrade labile carbon compounds, their activity shows how the microorganisms present in the soil under Conv management mineralize this carbon fraction to obtain nutrients, but not to promote carbon sequestration [70].

\subsection{Abundance of Bacterial Taxa}

Proteobacteria phyla abound when there is a high availability of nutrients due to an increase in $\mathrm{SOM}$, and also, they are able to consume labile organic carbon [71-73], which may suggest that the disposition of SOC in soil under Org management is subject to microbial decomposition of the SOM, and the velocity of this decomposition depends on, among other variables, the availability of 
nutrients [74]. The Actinobacteria phylum has diverse physiological properties, such as the production of extracellular enzymes for the decomposition of organic matter [75]. It has also been shown that Actinobacteria abundance is associated with the respiration rates of the soil [76,77], which agrees with the current study, since $\mathrm{CO}_{2}$ emission was greater under Conv management. Regarding bacterial genera that were more abundant in soil under Org management, Gemmata is capable of using glucose and galactose as a source of carbon in order to thrive, and therefore it is an important producer in the carbon and $\mathrm{N}$ cycles [78,79]. Likewise, it has been shown that Dongia and Pseudolabrys genera were significantly more abundant in the soils under non-tillage and addition of organic residues [80]. Regarding Zavarzinella, in spite of its importance, nowadays its isolation and behavior have been demonstrated in macroalgae [81], while there has been little or no research done in soils. Lastly, the Catelliglobosispora genera have also been positively correlated with sucrose [82] and have a high potential for the deconstruction of cellulose and chitin [83]. It seems probable that the establishment of vegetation covers and deposits of organic matter in Org management will promote sources of carbon, which increase the abundance of Gemmata, Dongia, and Pseudolabrys. Regarding the more representative genera under Conv management, Tepidisphaera hydrolyzes a broad range of carbohydrates, among which are glucose and galactose, essential components in SOM [84]. On the other hand, in agricultural soils, some species of Sphingomonas have shown the capacity for degrading chemical compounds of herbicides into $\mathrm{CO}_{2}$ that is liberated into the atmosphere [85], which may suggest that the abundance of both genera may be related to the SOM content and the mineralization process of carbon under this management.

The Streptomyces genera have been described at length for their adaptation to soils, where they are capable of forming hyphae that branch out to attach to and penetrate into insoluble organic residues from plants and other organisms, as well as recalcitrant insoluble inorganic polymers such as chitin and cellulose [86,87]. In this regard, studies show that the production of oxidative enzymes, such as LAC, associated with the population growth of Streptomyces, intervene in the degradation of lignocellulosic compounds [88,89]. Regarding Rhizomicrobium, a significant abundance has been reported in soils contaminated with fluoride and chloride [90] as well as in soils where organic residues are applied [80]. Finally, it has been shown that the Stenotrophobacter genera participate in the carbon and $\mathrm{N}$ cycle and respond to agronomic management [91,92]. These results suggest that the application of organic and inorganic compounds to the soil used in the conventional cultivation of pecan trees affects the bacterial abundance and functional diversity, which impacts the functional properties of the soil, particularly those related to carbon forms $[6,93,94]$. The results obtained from the CCA confirm that the bacterial communities in the soil were influenced by the type of management. Under the Org management, the Acidobacteria phylum was benefited by HS content. As was mentioned before, HS are the most recalcitrant fraction of organic soil due to the stabilization of SOC [31,48,95]. Rawat et al. [96] showed that Acidobacteria communities are essential to the cycle of carbon in the soil, and that its activity and dominion depend on them. Likewise, being classified as oligotrophic organisms, they are related to $\mathrm{C}$ sequestration, since it has been demonstrated that they are autotrophic and have the capacity to fix atmospheric $\mathrm{CO}_{2}$ in the soils of arid and semi-arid ecosystems [97,98], and thus contribute to the generation of organic carbon reservoirs [99,100]. Conversely, under Conv management, the bacterial communities of the Actinobacteria Phylum were influenced by the EEG, FA, and B-glu variables. Thereon, the change in the microbial community of fungi and Actinobacteria is due to the amounts of organic residues that result from the availability of resources $[6,72,101]$. It has been shown that both microbial communities are fundamental in the degradation process of complex compounds such as cellulose, lignin, and chitin [102], where Actinobacteria, in particular, present diverse physiological properties, such as the production of extracellular and metabolic enzymes related to the decomposition of SOM [75]. 


\section{Conclusions}

The use of organic practices in the cultivation of pecan trees seems to influence the concentration of nutrients and various chemical and biological variables in the soil, mainly in the capture of recalcitrant $\mathrm{C}$ compounds. Furthermore, this type of management could favor bacterial communities capable of promoting greater efficiency in organic carbon sequestration. On the other hand, conventional management practices influence the increase in carbon mineralization, as well as the enzymatic activity of the soil, particularly that of the enzymes related to the metabolism of labile compounds. The use of genomic technologies has allowed the discovery of the soil microbiome in recent years, however it is still necessary to understand the adaptation and plasticity of some bacterial communities and other soil microorganisms, as well as their functional biodiversity and soil-plant dynamics, which are essential in order to preserve the optimal state of the soil.

Author Contributions: Conceptualization, A.C.-R., E.N.-R., C.G.-D.1.P. and J.G.A.-Á.; data curation, A.C.-R., F.V.-P. and C.D.-V.; formal analysis, A.C.-R., E.N.-R. and M.M.C.; funding acquisition, E.N.-R. and R.T.-C.; investigation, A.C.-R.; methodology, A.C.-R., E.N.-R., C.G.-D.1.P., F.V.-P., C.D.-V. and V.C.-G.; project administration, E.N.-R.; resources, E.N.-R., R.T.-C. and C.G.-D.1.P.; software, A.C.-R., C.G.-D.1.P., F.V.-P. and C.D.-V.; supervision, E.N.-R., R.T.-C., C.G.-D.1.P., J.G.A.-Á. and M.M.C.; validation, A.C.-R., R.T.-C., C.G.-D.l.P. and J.G.A.-Á.; visualization, R.T.-C. and M.M.C.; writing-original draft, A.C.-R.; writing-review and editing, E.N.-R., R.T.-C., C.G.-D.1.P., J.G.A.-Á., M.M.C., F.V.-P., C.D.-V. and V.C.-G. All authors have read and agreed to the published version of the manuscript.

Funding: This research was funded by Ministry of Agriculture and Rural Development (SADER) of México, grant number 12281434630 and by Consejo Nacional de Ciencia y Tecnologia (CONACYT), by a graduate scholarship for the first author.

Acknowledgments: We are grateful to M.C. José Heriberto Aguilar Pérez and Nueces del Bravo SPR de RL for their help and facilities provided during the field work.

Conflicts of Interest: The authors declare no conflict of interest.

\section{References}

1. Delgado-Baquerizo, M.; Maestre, F.T.; Reich, P.B.; Trivedi, P.; Osanai, Y.; Liu, Y.R.; Hamonts, K.; Jeffries, T.C.; Singh, B.K. Carbon Content and Climate Variability Drive Global Soil Bacterial Diversity Patterns. Ecol. Monogr. 2016, 86, 373-380. [CrossRef]

2. Berthrong, S.T.; Buckley, D.H.; Drinkwater, L.E. Agricultural Management and Labile Carbon Additions Affect Soil Microbial Community Structure and Interact with Carbon and Nitrogen Cycling. Microb. Ecol. 2013, 66, 158-170. [CrossRef] [PubMed]

3. Coleman, D.; Wall, D. Soil Microbiology, Ecology and Biochemistry, 4th ed.; Academic: Boston, MA, USA, 2015; pp. 11-149.

4. Creamer, A.; de Menezes, B.; Krull, S.; Sanderman, J.; Newton-Walters, R.; Farrell, M. Corrigendum to "Microbial Community Structure Mediates Response of soil C Decomposition to Litter Addition and Warming. Soil Biol. Biochem. 2015, 83, 175-188. [CrossRef]

5. Jiménez-Bueno, N.G.; Valenzuela-Encinas, C.; Marsch, R.; Ortiz-Gutiérrez, D.; Verhulst, N.; Govaerts, B.; Dendooven, L.; Navarro-Noya, Y.E. Bacterial Indicator Taxa in Soils under Different Long-Term Agricultural Management. J. Appl. Microbiol. 2016, 120, 921-933. [CrossRef]

6. Mathew, R.P.; Feng, Y.; Githinji, L.; Ankumah, R.; Balkcom, K.S. Impact of No-Tillage and Conventional Tillage Systems on Soil Microbial Communities. Appl. Environ. Soil Sci. 2012, 2012, 1-10. [CrossRef]

7. Van Diepeningen, A.D.; De Vos, O.J.; Korthals, G.W.; Van Bruggen, A.H.C. Effects of Organic versus Conventional Management on Chemical and Biological Parameters in Agricultural Soils. Appl. Soil Ecol. 2006, 31, 120-135. [CrossRef]

8. Smith, F.P.; Prober, S.M.; House, A.P.N.; McIntyre, S. Maximizing Retention of Native Biodiversity in Australian Agricultural Landscapes-The 10:20:40:30 Guidelines. Agric. Ecosyst. Environ. 2013, 166, 35-45. [CrossRef]

9. Maffei, D.F.; Batalha, E.Y.; Landgraf, M.; Schaffner, D.W.; Franco, B.D.G.M. Microbiology of Organic and Conventionally Grown Fresh Produce. Braz. J. Microbiol. 2016, 47, 99-105. [CrossRef] 
10. Mishra, D.; Rajvir, S.; Mishra, U.; Kumar, S. Role of Bio-Fertilizer in Organic Agriculture: A Review. Res. J. Recent 2013, 2, 39-41.

11. Lee, K.H.; Jose, S. Soil Respiration and Microbial Biomass in a Pecan-Cotton Alley Cropping System in Southern USA. Agrofor. Syst. 2003, 58, 45-54. [CrossRef]

12. Kremer, R.J.; Kussman, R.D. Soil Quality in a Pecan-Kura Clover Alley Cropping System in the Midwestern USA. Agrofor. Syst. 2011, 83, 213-223. [CrossRef]

13. Duchene, O.; Vian, J.F.; Celette, F. Intercropping with Legume for Agroecological Cropping Systems: Complementarity and Facilitation Processes and the Importance of Soil Microorganisms. A Review. Agric. Ecosyst. Environ. 2017, 240, 148-161. [CrossRef]

14. Pérez, H. Manual Para El Manejo Orgánico Del Nogal Pecanero; Palibrio: Bloomington, IN, USA, $2014 ;$ p. 274.

15. Malik, N.S.A.; Perez, J.L.; Lombardini, L.; Cornacchia, R.; Cisneros-Zevallosb, L.; Braforda, J. Phenolic Compounds and Fatty Acid Composition of Organic and Conventional Grown Pecan Kernels. J. Sci. Food Agric. 2009, 89, 2207-2213. [CrossRef]

16. FAO. FAOSTAT, Produccion de Nuez Con Cáscara. 2018. Available online: http://www.fao.org/faostat/es/ \#data/QC (accessed on 21 April 2020).

17. SADER. Panorama Agroalimentario 2019. Available online: https://federacion-anech.org/2019/11/14/atlasagroalimentario-2019/ (accessed on 21 April 2020).

18. Mungai, N.W.; Motavalli, P.P.; Kremer, R.J. Soil Organic Carbon and Nitrogen Fractions in Temperate Alley Cropping Systems. Commun. Soil Sci. Plant Anal. 2006, 37, 977-992. [CrossRef]

19. Bai, C.; Reilly, C.C.; Wood, B.W. Nickel Deficiency Disrupts Metabolism of Ureides, Amino Acids, and Organic Acids of Young Pecan Foliage. Plant Physiol. 2006, 140, 433-443. [CrossRef]

20. Brown, V.; Braun de Torrez, E.; McCracken, G. Crop Pests Eaten by Bats in Organic Pecan Orchards. Crop Prot. 2015, 67, 66-71. [CrossRef]

21. INIFAP; CONABIO. Instituto Nacional de Investigaciones Forestales y Agropecuarias (INIFAP)—Comisión Nacional para el Conocimiento y Uso de la Biodiversidad (CONABIO), (1995). "Edafología". Escalas 1:250000 y 1:1000000. México. Available online: http://www.conabio.gob.mx/informacion/gis/ (accessed on 2 November 2020).

22. INEGI. Prontuario de Información Geográfica Municipal, Allende, Coahuila de Zaragoza. Available online: http://www3.inegi.org.mx/contenidos/app/mexicocifras/datos_geograficos/05/05030.pdf (accessed on 2 April 2020).

23. INIFAP. Tecnología de Producción En Nogal Pecanero, Prmera; Salinas, H., Quiroga, H., Tijerina, A., Figueroa, U., Eds.; INIFAP-SAGARPA: Matamoros, Mexico, 2002; p. 221.

24. Jackson, L. Análisis Químico de Suelos, 4th ed.; Beltrán, M., Ed.; Omega: Barcelona, Spain, 1982; p. 662.

25. Bremner, J.M. Inorganic Forms of Nitrogen in Soil. In Methods of Soil Analysis; Black, C.A., Ed.; Crop Science Society of America: Ames, IA, USA, 1965; pp. 1179-1237. [CrossRef]

26. Olsen, S.; Sommers, L. Phosphurus. In Methods of Soil Analysis; American Society of Agronomy: Madison, WI, USA, 1982; pp. 404-430.

27. Thomas, G. Exchangeable Cations. In Methods of Soil Analysis; Black, C.A., Ed.; American Society of Agronomy: Madison, WI, USA, 1982; pp. 159-165.

28. Walkley, A.; Black, I. An Examination of Degtjareff Method for Determining Soil Organic Matter and a Proposed Modification of the Chromic Acid Titration Method. Soil Sci. 1934, 37, 29-37. [CrossRef]

29. Anderson, D.; Schoenau, J. Soli Humus Fractions. In Soli Sampling Methods of Analysis; Carter, M., Ed.; CRC Press: Boca Ratón, FL, USA, 1993; pp. 391-395.

30. Dębska, B.; Długosz, J.; Piotrowska-Długosz, A.; Banach-Szott, M. The Impact of a Bio-Fertilizer on the Soil Organic Matter Status and Carbon Sequestration-Results from a Field-Scale Study. J. Soils Sediments 2016, 16, 2335-2343. [CrossRef]

31. Chan, K.Y.; Bowman, A.; Oates, A. Oxidizible Organic Carbon Fractions and Soil Quality Changes in an Oxic Paleustalf under Different Pasture Leys. Soil Sci. 2001, 166, 61-67. [CrossRef]

32. Brookes, P.; Landman, A.; Pruden, G.; Jenkinson, D. Chloroform Fumigation and the Release of Soil Nitrogen; a Rapid Direct Extraction Method to Measure Microbial Biomasa Nitrogen in Soil. Soil Biol. Biochem. 1985, 17, 837-842. [CrossRef]

33. Rillig, M.C.; Ramsey, P.W.; Morris, S.; Paul, E.A. Glomalin, an Arbuscular-Mycorrhizal Fungal Soil Protein, Responds to Land-Use Change. Plant Soil 2003, 253, 293-299. [CrossRef] 
34. Guerrero, P.; Quintero, R.; Espinoza, V.; Benedicto, G.; Sanchez, M. Respiration of $\mathrm{CO}_{2}$ as an Indicator of Microbial Activity in Organic Fertilizers of Lupinus. Terra Latinoam. 2012, 30, 355-362.

35. García, A.; Rivero, C. Evaluación Del Carbono Microbiano y La Respiración Basal En Respuesta a La Aplicación de Lodo Papelero En Los Suelos de La Cuenca Del Lago de Valencia. Rev. Fac. Agron. 2008, 34, 215-229.

36. Saiya-Cork, K.R.; Sinsabaugh, R.L.; Zak, D.R. The Effects of Long Term Nitrogen Deposition on Extracellular Enzyme Activity in an Acer saccharum Forest Soil. Soil Biol. Biochem. 2002, 34, 1309-1315. [CrossRef]

37. Bourbonnais, R.; Paice, M.G. Oxidation of Non-Phenolic Substrates. FEBS Lett. 1990, 267, 99-102. [CrossRef]

38. Tabatabai, M. Soil Enzymes. In Methods of Soil Analysis; Weavwe, R., Ed.; American Society of Agronomy: Madison, WI, USA, 1994; pp. 775-833.

39. Klindworth, A.; Pruesse, E.; Schweer, T.; Peplies, J.; Quast, C.; Horn, M.; Glöckner, F.O. Evaluation of General 16S Ribosomal RNA Gene PCR Primers for Classical and Next-Generation Sequencing-Based Diversity Studies. Nucleic Acids Res. 2013, 41, 1-11. [CrossRef] [PubMed]

40. Illumina. 16S Metagenomic Sequencing Library Preparation, Preparing 16S Ribosomal RNA Gene Amplicons for the Illumina MiSeq System. Available online: https:/emea.illumina.com/content/dam/ illuminasupport/documents/documentation/chemistry_documentation/16s/16s-metagenomic-libraryprep-guide-15044223-b.pdf (accessed on 20 February 2019).

41. Illumina. Nextera XT DNA Library Prep Kit Reference Guide. Available online: https://support.illumina.com/content/dam/illumina-support/documents/documentation/chemistry_ documentation/samplepreps_nextera/nextera-xt/nextera-xt-library-prep-reference-guide-15031942-05.pdf (accessed on 20 February 2019).

42. Caporaso, J.G.; Fierer, N.; Peña, A.G.; Goodrich, J.K.; Gordon, J.I.; Huttley, G.A.; Kelley, S.T.; Knights, D.; McDonald, D.; Muegge, B.D.; et al. QIIME Allows Analysis of High-Throughput Community Sequencing Data. Nat. Methods 2010, 7, 335-336. [CrossRef] [PubMed]

43. García-De la Peña, C.; Garduño-Niño, E.; Vaca-Paniagua, F.; Díaz-Velásquez, C.; Barrows, C.; Gomez-Gil, B.; Valenzuela-Núñez, L. Comparison of the Fecal Bacterial Microbiota Composition between Wild and Captive Bolson Tortoises (Gopherus flavomarginatus). Herpetol. Conserv. Biol. 2019, 14, 587-600.

44. Hammer, Ø.; Harper, D.A.T.; Ryan, P.D. Past: Paleontological Statistics Software Package for Education and Data Analysis. Palaeontol. Electron. 2001, 4, 1-9.

45. Compton, J.E.; Watrud, L.S.; Porteous, L.A.; DeGrood, S. Response of Soil Microbial Biomass and Community Composition to Chronic Nitrogen Additions at Harvard Forest. For. Ecol. Manag. 2004, 196, 143-158. [CrossRef]

46. Idowu, O.J.; Sanogo, S.; Brewer, C.E. Short-Term Impacts of Pecan Waste By-Products on Soil Quality in Texturally Different Arid Soils. Commun. Soil Sci. Plant Anal. 2017, 48, 1781-1791. [CrossRef]

47. Kruse, J.; Abraham, M.; Amelung, W.; Baum, C.; Bol, R.; Kühn, O.; Lewandowski, H.; Niederberger, J.; Oelmann, Y.; Rüger, C.; et al. Innovative Methods in Soil Phosphorus Research: A Review. J. Plant Nutr. Soil Sci. 2015, 178, 43-88. [CrossRef] [PubMed]

48. Benbi, D.K.; Brar, K.; Toor, A.S.; Singh, P.; Singh, H. Soil Carbon Pools under Poplar-Based Agroforestry, Rice-Wheat, and Maize-Wheat Cropping Systems in Semi-Arid India. Nutr. Cycl. Agroecosyst. 2012, 92, 107-118. [CrossRef]

49. Mäder, P.; Fließbach, A.; Dubois, D.; Gunst, L.; Fried, P.; Niggli, U. Soil Fertility and Biodiversity in Organic Farming. Science 2002, 296, 1694-1697. [CrossRef]

50. Culman, S.W.; DuPont, S.T.; Glover, J.D.; Buckley, D.H.; Fick, G.W.; Ferris, H.; Crews, T.E. Long-Term Impacts of High-Input Annual Cropping and Unfertilized Perennial Grass Production on Soil Properties and Belowground Food Webs in Kansas, USA. Agric. Ecosyst. Environ. 2010, 137, 13-24. [CrossRef]

51. Liu, E.; Yan, C.; Mei, X.; Zhang, Y.; Fan, T. Long-Term Effect of Manure and Fertilizer on Soil Organic Carbon Pools in Dryland Farming in Northwest China. PLoS ONE 2013, 8, 1-9. [CrossRef]

52. Brookes, P.; Cayuela, M.L.; Contin, M.; De Nobili, M.; Kemmitt, S.J.; Mondini, C. The Mineralisation of Fresh and Humified Soil Organic Matter by the Soil Microbial Biomass. Waste Manag. 2008, 28, 716-722. [CrossRef]

53. de Souza, G.P.; de Figueiredo, C.C.; de Sousa, D.M.G. Relationships between Labile Soil Organic Carbon Fractions under Different Soil Management Systems. Sci. Agric. 2016, 73, 535-542. [CrossRef]

54. Martínez, E.; Fuentes, J.P.; Acevedo, E. Carbono Orgánico y Propiedades Del Suelo. Revista de la Ciencia del Suelo y Nutrición Vegetal 2008, 8, 68-96. [CrossRef]

55. Ginebra, M.; Rodríguez, M.; Calero, B.; Ponce de León, D.; Font, L. The Labile Carbon as Indicator of Changes in Two Soils under Different Uses. Cultiv. Trop. 2015, 36, 64-70. 
56. Dignac, M.F.; Derrien, D.; Barré, P.; Barot, S.; Cécillon, L.; Chenu, C.; Chevallier, T.; Freschet, G.T.; Garnier, P.; Guenet, B.; et al. Increasing Soil Carbon Storage: Mechanisms, Effects of Agricultural Practices and Proxies. A Review. Agron. Sustain. Dev. 2017, 37, 1-27. [CrossRef]

57. Lejon, D.; Sebastia, J.; Lamy, I.; Chaussod, R.; Ranjard, L. Relationships between Soil Organic Status and Microbial Community Density and Genetic Structure in Two Agricultural Soils Submitted to Various Types of Organic Management. Microb. Ecol. 2007, 53, 650-663. [CrossRef]

58. Abril, A.; Noe, L.; Filippini, M.F. Manejo de Enmiendas Para Restaurar La Materia Orgánica Del Suelo En Oasis de Regadío de Mendoza, Argentina. Rev. Investig. Agropecu. 2014, 40, 83-91.

59. Vásquez, J.R.; Macías, F.; Menjivar, J.C. Respiración Del Suelo Según Su Uso y Su Relación Con Algunas Formas de Carbono En El Departamento Del Magdalena, Colombia. Bioagro 2013, 25, 175-180.

60. Álvaro-Fuentes, J.; Cantero-Martínez, C.; López, M.; Arrúe, J. Fijación de Carbono y Reducción de Emisiones de $\mathrm{CO}_{2}$. In Aspectos Agronómicos y Medioambientales de la Agricultura de Conservación; González, E.K., Ordóñez, R., Gil, J.A., Eds.; Ministerio de Medio Ambiente y Medio Rural y Marino: Zaragoza, Spain, 2010; pp. 89-96.

61. Jinbo, Z.; Changchun, S.; Wenyan, Y. Land Use Effects on the Distribution of Labile Organic Carbon Fractions through Soil Profiles. Soil Sci. Soc. Am. J. 2006, 70, 660-667. [CrossRef]

62. Stockmann, U.; Adams, M.A.; Crawford, J.W.; Field, D.J.; Henakaarchchi, N.; Jenkins, M.; Minasny, B.; McBratney, A.B.; De Courcelles, V.D.R.; Singh, K.; et al. The Knowns, Known Unknowns and Unknowns of Sequestration of Soil Organic Carbon. Agric. Ecosyst. Environ. 2013, 164, 80-99. [CrossRef]

63. Báez-Pérez, A.; González-Chávez, M.C.Á.; Etchevers-Barra, J.D.; Prat, C.; Hidalgo-Moreno, C. Glomalina y Secuestro de Carbono En Tepetates Cultivados. Agrociencia 2010, 44, 517-529.

64. Treseder, K.K.; Turner, K.M. Glomalin in Ecosystems. Soil Sci. Soc. Am. J. 2007, 71, 1257-1266. [CrossRef]

65. Otto, B.; Schlosser, D.; Reisser, W. First Description of a Laccase-like Enzyme in Soil Algae. Arch. Microbiol. 2010, 192, 759-768. [CrossRef]

66. Rivera-Hoyos, C.M.; Morales-Álvarez, E.D.; Poutou-Piñales, R.A.; Pedroza-Rodríguez, A.M.; RodrÍguez-Vázquez, R.; Delgado-Boada, J.M. Fungal Laccases. Fungal Biol. Rev. 2013, 27, 67-82. [CrossRef]

67. Sardans, J.; Peñuelas, J.; Estiarte, M. Changes in Soil Enzymes Related to C and N Cycle and in Soil C and N Content under Prolonged Warming and Drought in a Mediterranean Shrubland. Appl. Soil Ecol. 2008, 39, 223-235. [CrossRef]

68. Aragón, R.; Sardans, J.; Peñuelas, J. Soil Enzymes Associated with Carbon and Nitrogen Cycling in Invaded and Native Secondary Forests of Northwestern Argentina. Plant Soil 2014, 384, 169-183. [CrossRef]

69. Zhang, X.; Dong, W.; Dai, X.; Schaeffer, S.; Yang, F.; Radosevich, M.; Xu, L.; Liu, X.; Sun, X. Responses of Absolute and Specific Soil Enzyme Activities to Long Term Additions of Organic and Mineral Fertilizer. Sci. Total Environ. 2015, 536, 59-67. [CrossRef]

70. Kotroczó, Z.; Veres, Z.; Fekete, I.; Krakomperger, Z.; Tóth, J.A.; Lajtha, K.; Tóthmérész, B. Soil Enzyme Activity in Response to Long-Term Organic Matter Manipulation. Soil Biol. Biochem. 2014, 70, 237-243. [CrossRef]

71. Vigdis, T.; Øvreås, L. Microbial Diversity, Life Strategies, and Adaptation to Life in Extreme Soils. In Microbiology of Extreme Soils; Dion, P., Shekhar, C., Eds.; Springer: Berlin/Heidelberg, Germany, 2008; Volume 16, pp. 15-43. [CrossRef]

72. Carbonetto, B.; Rascovan, N.; Álvarez, R.; Mentaberry, A.; Vázquez, M.P. Structure, Composition and Metagenomic Profile of Soil Microbiomes Associated to Agricultural Land Use and Tillage Systems in Argentine Pampas. PLoS ONE 2014, 9, 1-11. [CrossRef]

73. Pan, Y.; Cassman, N.; de Hollander, M.; Mendes, L.W.; Korevaar, H.; Geerts, R.H.E.M.; van Veen, J.A.; Kuramae, E.E. Impact of Long-Term N, P, K, and NPK Fertilization on the Composition and Potential Functions of the Bacterial Community in Grassland Soil. FEMS Microbiol. Ecol. 2014, 90, 195-205. [CrossRef]

74. Rabbi, S.M.F.; Daniel, H.; Lockwood, P.V.; Macdonald, C.; Pereg, L.; Tighe, M.; Wilson, B.R.; Young, I.M. Physical Soil Architectural Traits Are Functionally Linked to Carbon Decomposition and Bacterial Diversity. Sci. Rep. 2016, 6, 1-9. [CrossRef]

75. Goodfellow, M.; Williams, S.T. Ecology of Actinomycetes. Annu. Rev. Microbiol. 1983, 37, 189-216. [CrossRef]

76. Ozdemir-Kocak, F.; Isik, K.; Saricaoglu, S.; Saygin, H.; Inan-Bektas, K.; Cetin, D.; Guven, K.; Sahin, N. Kribbella sindirgiensis sp. Nov. Isolated from Soil. Arch. Microbiol. 2017, 199, 1399-1407. [CrossRef] 
77. Liu, Y.R.; Delgado-Baquerizo, M.; Yang, Z.; Feng, J.; Zhu, J.; Huang, Q. Microbial Taxonomic and Functional Attributes Consistently Predict Soil $\mathrm{CO}_{2}$ Emissions across Contrasting Croplands. Sci. Total Environ. 2020, 702, 1-8. [CrossRef]

78. Devos, D.P. Gemmata obscuriglobus. Curr. Biol. 2013, 23, 705-707. [CrossRef] [PubMed]

79. Fuerst, J.A.; Lee, K.-C.; Butler, M.K. Gemmata. Bergey's Man. Syst. Archaea Bact. 2015, 1-5. [CrossRef]

80. Wang, H.; Li, X.; Li, X.; Wang, J.; Li, X.; Guo, Q.; Yu, Z.; Yang, T.; Zhang, H. Long-Term No-Tillage and Different Residue Amounts Alter Soil Microbial Community Composition and Increase the Risk of Maize Root Rot in Northeast China. Soil Tillage Res. 2020, 196, 104452. [CrossRef]

81. Faria, M.; Bordin, N.; Kizina, J.; Harder, J.; Devos, D.; Lage, O.M. Planctomycetes Attached to Algal Surfaces: Insight into Their Genomes. Genomics 2018, 110, 231-238. [CrossRef]

82. Sun, J.; Zhang, Q.; Zhou, J.; Wei, Q. Pyrosequencing Technology Reveals the Impact of Different Manure Doses on the Bacterial Community in Apple Rhizosphere Soil. Appl. Soil Ecol. 2014, 78, 28-36. [CrossRef]

83. Talamantes, D.; Biabini, N.; Dang, H.; Abdoun, K.; Berlemont, R. Natural Diversity of Cellulases, Xylanases, and Chitinases in Bacteria. Biotechnol. Biofuels 2016, 9, 1-11. [CrossRef]

84. Kovaleva, O.L.; Elcheninov, A.G.; Kublanov, I.V.; Bonch-Osmolovskaya, E. Tepidisphaera. Bergey's Man. Syst. Archaea Bact. 2019, 1, 1-5. [CrossRef]

85. Sørensen, S.; Ronen, Z.; Aamand, J. Isolation from Agricultural Soil and Characterization of a Sphingomonas sp. Able to Mineralize the Phenylurea Herbicide Isoproturon. Society 2001, 67, 5403-5409. [CrossRef]

86. Chater, K.F.; Biró, S.; Lee, K.J.; Palmer, T.; Schrempf, H. The Complex Extracellular Biology of Streptomyces. FEMS Microbiol. Rev. 2010, 34, 171-198. [CrossRef]

87. Seipke, R.F.; Kaltenpoth, M.; Hutchings, M.I. Streptomyces as Symbionts: An Emerging and Widespread Theme? FEMS Microbiol. Rev. 2012, 36, 862-876. [CrossRef]

88. de Orué Lucana, D.O.; Schaa, T.; Schrempf, H. The Novel Extracellular Streptomyces reticuli Haem-Binding Protein HbpS Influences the Production of the Catalase-Peroxidase CpeB. Microbiology 2004, 150, 2575-2585. [CrossRef]

89. Tuncer, M.; Kuru, A.; Isikli, M.; Sahin, N.; Çelenk, F.G. Optimization of Extracellular Endoxylanase, Endoglucanase and Peroxidase Production by Streptomyces sp. F2621 Isolated in Turkey. J. Appl. Microbiol. 2004, 97, 783-791. [CrossRef]

90. Wu, S.; Li, Y.; Wang, P.; Zhong, L.; Qiu, L.; Chen, J. Shifts of Microbial Community Structure in Soils of a Photovoltaic Plant Observed Using Tag-Encoded Pyrosequencing of 16S RRNA. Appl. Microbiol. Biotechnol. 2016, 100, 3735-3745. [CrossRef]

91. Pascual, J.; Huber, K.J.; Foesel, B.U.; Overmann, J. Stenotrophobacter. Bergey's Man. Syst. Archaea Bact. 2017, 1, 1-8. [CrossRef]

92. Li, W.H.; Liu, Q.Z.; Chen, P. Effect of Long-Term Continuous Cropping of Strawberry on Soil Bacterial Community Structure and Diversity. J. Integr. Agric. 2018, 17, 2570-2582. [CrossRef]

93. Marschner, P.; Kandeler, E.; Marschner, B. Structure and Function of the Soil Microbial Community in a Long-Term Fertilizer Experiment. Soil Biol. Biochem. 2003, 35, 453-461. [CrossRef]

94. Yu, C.; Hu, X.M.; Deng, W.; Li, Y.; Xiong, C.; Ye, C.H.; Han, G.M.; Li, X. Changes in Soil Microbial Community Structure and Functional Diversity in the Rhizosphere Surrounding Mulberry Subjected to Long-Term Fertilization. Appl. Soil Ecol. 2015, 86, 30-40. [CrossRef]

95. Simpson, A.J.; Song, G.; Smith, E.; Lam, B.; Novotny, E.H.; Hayes, M.H.B. Unraveling the Structural Components of Soil Humin by Use of Solution-State Nuclear Magnetic Resonance Spectroscopy. Environ. Sci. Technol. 2007, 41, 876-883. [CrossRef] [PubMed]

96. Rawat, S.R.; Männistö, M.K.; Bromberg, Y.; Häggblom, M.M. Comparative Genomic and Physiological Analysis Provides Insights into the Role of Acidobacteria in Organic Carbon Utilization in Arctic Tundra Soils. FEMS Microbiol. Ecol. 2012, 82, 341-355. [CrossRef]

97. Eichorst, S.A.; Trojan, D.; Roux, S.; Herbold, C.; Rattei, T.; Woebken, D. Genomic Insights into the Acidobacteria Reveal Strategies for Their Success in Terrestrial Environments. Environ. Microbiol. 2018, 20, 1041-1063. [CrossRef]

98. Zhao, K.; Kong, W.; Wang, F.; Long, X.E.; Guo, C.; Yue, L.; Yao, H.; Dong, X. Desert and Steppe Soils Exhibit Lower Autotrophic Microbial Abundance but Higher Atmospheric $\mathrm{CO}_{2}$ Fixation Capacity than Meadow Soils. Soil Biol. Biochem. 2018, 127, 230-238. [CrossRef]

99. Miltner, A.; Richnow, H.H.; Kopinke, F.D.; Kästner, M. Assimilation of $\mathrm{CO}_{2}$ by Soil Microorganisms and Transformation into Soil Organic Matter. Org. Geochem. 2004, 35, 1015-1024. [CrossRef] 
100. Videmšek, U.; Hagn, A.; Suhadolc, M.; Radl, V.; Knicker, H.; Schloter, M.; Vodnik, D. Abundance and Diversity of $\mathrm{CO}_{2}$-Fixing Bacteria in Grassland Soils Close to Natural Carbon Dioxide Springs. Microb. Ecol. 2009, 58, 1-9. [CrossRef] [PubMed]

101. Arcand, M.M.; Helgason, B.L.; Lemke, R.L. Microbial Crop Residue Decomposition Dynamics in Organic and Conventionally Managed Soils. Appl. Soil Ecol. 2016, 107, 347-359. [CrossRef]

102. Singh, G.; Bhattacharyya, R.; Das, T.K.; Sharma, A.R.; Ghosh, A.; Das, S.; Jha, P. Crop Rotation and Residue Management Effects on Soil Enzyme Activities, Glomalin and Aggregate Stability under Zero Tillage in the Indo-Gangetic Plains. Soil Tillage Res. 2018, 184, 291-300. [CrossRef]

Publisher's Note: MDPI stays neutral with regard to jurisdictional claims in published maps and institutional affiliations.

(C) 2020 by the authors. Licensee MDPI, Basel, Switzerland. This article is an open access article distributed under the terms and conditions of the Creative Commons Attribution (CC BY) license (http://creativecommons.org/licenses/by/4.0/). 